\title{
The prioritisation of invasive alien plant control projects using a multi-criteria decision model informed by stakeholder input and spatial data
}

\author{
G.G. Forsyth ${ }^{\mathrm{a}, *}$, D.C. Le Maitre ${ }^{\mathrm{a}}$, P.J. O’Farrell ${ }^{\mathrm{a}}$, B.W. van Wilgen ${ }^{\mathrm{b}}$ \\ ${ }^{a}$ CSIR Natural Resources and the Environment, P.O. Box 320, Stellenbosch 7599, South Africa \\ ${ }^{\mathrm{b}}$ Centre for Invasion Biology, CSIR Natural Resources and the Environment, P.O. Box 320, Stellenbosch 7599, South Africa
}

\section{A R T I C L E I N F O}

\section{Article history:}

Received 28 January 2011

Received in revised form

22 December 2011

Accepted 15 January 2012

Available online 28 March 2012

\section{Keywords:}

Analytic hierarchy process

Ecosystem services

Fynbos

Karoo

South Africa

Working for Water

\begin{abstract}
A B S T R A C T
Invasions by alien plants are a significant threat to the biodiversity and functioning of ecosystems and the services they provide. The South African Working for Water program was established to address this problem. It needs to formulate objective and transparent priorities for clearing in the face of multiple and sometimes conflicting demands. This study used the analytic hierarchy process (a multi-criteria decision support technique) to develop and rank criteria for prioritising alien plant control operations in the Western Cape, South Africa. Stakeholder workshops were held to identify a goal and criteria and to conduct pair-wise comparisons to weight the criteria with respect to invasive alien plant control. The combination of stakeholder input (to develop decision models) with data-driven model solutions enabled us to include many alternatives (water catchments), that would otherwise not have been feasible. The most important criteria included the capacity to maintain gains made through control operations, the potential to enhance water resources and conserve biodiversity, and threats from priority invasive alien plant species. We selected spatial datasets and used them to generate weights that could be used to objectively compare alternatives with respect to agreed criteria. The analysis showed that there are many high priority catchments which are not receiving any funding and low priority catchments which are receiving substantial allocations. Clearly, there is a need for realigning priorities, including directing sufficient funds to the highest priority catchments to provide effective control. This approach provided a tractable, consensus-based solution that can be used to direct clearing operations. (C) 2012 Elsevier Ltd. All rights reserved.
\end{abstract}

\section{Introduction}

Invasions by alien plant species pose major threats to the biodiversity and functioning of ecosystems and the services they provide (Mack et al., 2000). In South Africa, woody alien plant species have significant impacts on the production of water (Le Maitre et al., 1996) as well as on other ecosystem services (Richardson and van Wilgen, 2004; van Wilgen et al., 2008). This is a critical issue as the country's available water resources are already fully utilised (DWAF, 2004). The national alien plant control program, Working for Water, was established in 1995 in response to this pressing concern (van Wilgen et al., 1998, 2010). Working for Water's primary goal is "the reduction of impact of existing priority invasive alien plant problems" (Working for Water, 2007). The protection of other ecosystem services, of biodiversity, and the opportunity to create employment in economically disadvantaged

\footnotetext{
* Corresponding author. Tel.: +27 21888 2400; fax: +27 218882693.

E-mail address: gforsyth@csir.co.za (G.G. Forsyth).
}

communities were regarded as further motivating factors (Magadlela and Mdzeke, 2004; Working for Water, 2007). Despite being one of the largest invasive alien plant control programs of its kind in the world, there are insufficient resources to reach all invaded areas and all invasive species, and decisions relating to where and when to control invasive alien plants must be made.

The problem of making choices within a given set of constraints and objectives has been a focus of management-related sciences for many years. Sophisticated approaches (such as multi-criteria decision making) have been developed to allow for multiple objectives and constraints to be simultaneously considered in relation to information which varies in both type and quality (Saaty, 1990). This information includes objective facts, expert knowledge, and opinions, and can come from diverse groups of stakeholders. Multi-criteria analysis has been found to be useful when seeking to accommodate the goals of different stakeholder groups (Qureshi and Harrison, 2001; Herath, 2004). The responsibilities for different aspects of environmental management are typically divided among several stakeholders, including government departments responsible for conservation, water resources, 
forestry, agriculture and social development, as well as the private sector. The analytic hierarchy process (AHP) is a multi-criteria analysis method which has been extensively used in large numbers of studies that include those where there are seemingly conflicting objectives (see Omkarprasad and Kumar, 2006 for a review of such studies). AHP is a consensus model that is particularly applicable to situations where all parties agree to negotiate in order to resolve conflict (Regan et al., 2006), because it combines the opinions expressed by many experts into a single comparison that incorporates all viewpoints (Ramanathan, 2001).

There is consensus among almost all of the stakeholders that manage rural land in South Africa of the need to reduce the negative impacts of invasive alien plants on ecosystems at a landscape scale. Although numerous studies have developed priorities and screening systems for alien plant species (e.g. Pheloung et al., 1999; FAO, 2003; Groves et al., 2003; Robertson et al., 2003; Nel et al., 2004; Mgidi et al., 2007), these have been based primarily on the risks of impacts brought about by these species, or on environmental attributes (Moody and Mack, 1988; Ruesink et al., 1995; Rouget et al., 2004a; Hauser and McCarthy, 2009). Most studies have not explicitly considered spatial aspects relating to species' known or predicted range (Higgins et al., 2000; Olenick et al., 2004; van Wilgen et al., 2007; Skurka Darin et al., 2011), and those that do consider spatial issues have been focussed at the project or clearing operation level and not at larger spatial scales involving many projects (e.g. Roura-Pascual et al., 2009).

Working for Water has always had a strong focus on water resources and consequently their management structure has developed around the management of catchment areas (van Wilgen et al., 1998). South Africa is divided into 21 primary (1st order) catchments (i.e. river basins), and these provide a focus for the highest level of water resource management (DWAF, 2004). The primary catchments are sub-divided hierarchically into smaller catchments, with the smallest management unit being a quaternary (4th order) catchment (i.e. watershed). There are 1911 such quaternary catchments in South Africa and Lesotho, and they tend to be larger in areas with low relief and drier climates (median size $436 \mathrm{~km}^{2}$, range $48-1810 \mathrm{~km}^{2}$ ).

This paper presents an approach for the prioritisation of quaternary catchments within primary catchments, for the purposes of invasive alien plant control, using AHP to develop and rank criteria for the prioritisation. Our approach complements the studies by Roura-Pascual et al. (2009) and van Wilgen et al. (2007) which report on approaches developed to assist managers in establishing priorities for operational management.

\section{Methods}

\subsection{Study area}

Our study focussed on six primary catchments (Fig. 1) collectively containing 309 quaternary catchments in the Western Cape region, one of Working for Water's nine management regions in South Africa. This region corresponds largely with the boundaries of the Western Cape Province and includes most of the Fynbos (Mediterranean-climate shrubland) biome, a large portion of the Succulent Karoo (arid shrubland) biome, some of the Nama Karoo biome and small areas of other biomes (Fig. 2; Mucina and Rutherford, 2006). The first two biomes are recognised as global biodiversity hotspots (Mittermeier et al., 1998). The main agricultural activities in the area include irrigated fruit orchards, irrigated and dryland vineyards, dryland cropping, and commercial pine plantations. In more arid areas, extensive livestock and game farming are the major land use practices. Flowers, reeds (Restionaceae) for thatching, and rooibos and honey bush tea are

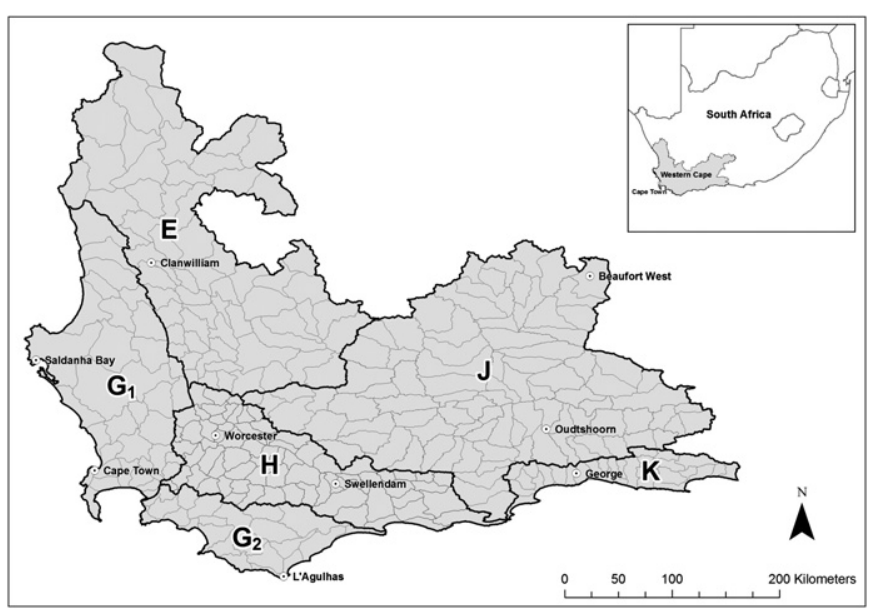

Fig. 1. Primary and quaternary catchments in Working for Water's Western Cape region, South Africa. Quaternary catchments were prioritised within primary catchments in this study. Primary catchments, and the number of quaternary catchments in each were: E, Olifants/Doring (63); $\mathrm{G}_{1}$, Berg (36); $\mathrm{G}_{2}$, Overberg (22); H, Breede (69); J, Gouritz (91); K, Garden Route (28).

harvested from fynbos vegetation (Turpie et al., 2003), while fuel wood, fibre, aloe leaves, herbs and medicinal plants are harvested in the Succulent and Nama Karoo biomes (Blignaut et al., 2005; Shackleton et al., 2008). Invasive alien plants that invade fynbos shrublands in mountain catchment areas have significant impacts on water resources, other ecosystem services and biodiversity (Le Maitre et al., 2000; van Wilgen et al., 2008). The dominant invaders (Table 1) and invasion patterns differ between these biomes (Richardson et al., 1997), and this needs to be taken into account when determining priorities. Fynbos shrublands are particularly susceptible to invasion by trees and shrubs in the genera Pinus (pines), Acacia (wattles) and Hakea (shrubs in the family Proteaceae). The Succulent and Nama Karoo areas are prone to invasions by shrubs, succulents and grasses, with tree and shrub species confined to river courses.

\subsection{Multi-criteria decision making}

We used a multi-criteria approach known as the analytic hierarchy process (AHP; Saaty, 1990) to identify and weight criteria for

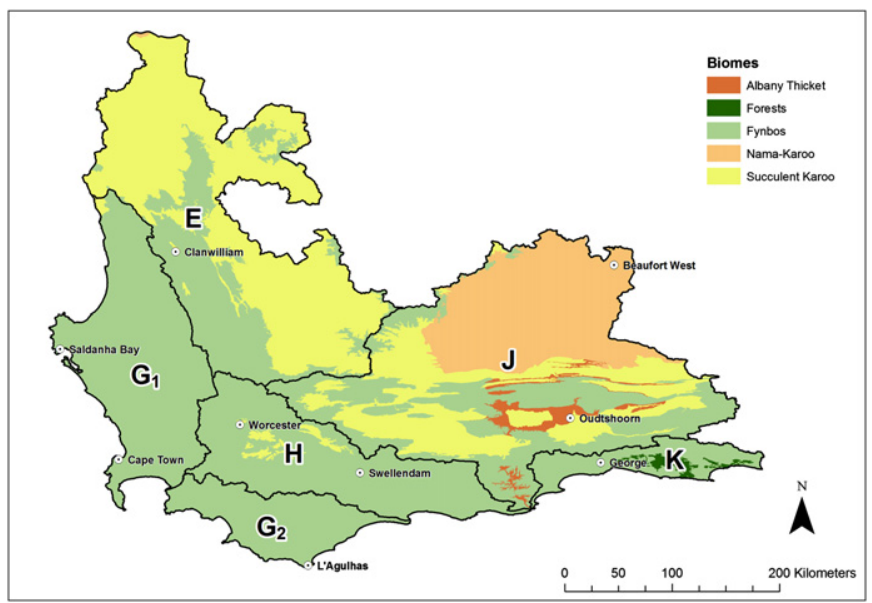

Fig. 2. Terrestrial biomes in the primary catchments of Working for Water's Western Cape region. 
Table 1

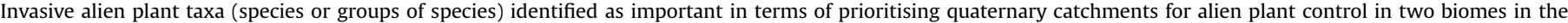
Western Cape region, South Africa. Rank indicates the relative importance assigned to the taxon following pair-wise comparisons by stakeholders.

\begin{tabular}{|c|c|c|c|c|}
\hline Biome & Taxon & Growth form & Habitat invaded & Rank \\
\hline \multirow[t]{9}{*}{ Fynbos } & Acacia mearnsii De Wild. (black wattle) & Tree & Lowlands and riparian zones & 1 \\
\hline & Pinus species (pines) & Tree & Mountain catchment areas & 2 \\
\hline & Populus species (poplars) & Tree & Riparian zones & 3 \\
\hline & A. pycnantha Benth. (golden wattle) & Tree & Lowlands and riparian zones & 4 \\
\hline & A. longifolia (Andr.) Willd. (long-leaved wattle) & Tree & Lowlands and riparian zones & 5 \\
\hline & A. saligna (Labill.) H.L.Wendl. (Port Jackson willow) & Tree & Lowlands and riparian zones & 6 \\
\hline & Paraserianthes lophantha (Willd.) Nielsen (stink bean) & Tree & Lowlands and riparian zones & 7 \\
\hline & Eucalyptus camaldulensis Dehnh. (red river gum) & Tree & Riparian zones & 8 \\
\hline & Hakea sericea Schrad. \& J.C.Wendl. (silky hakea) & Tall shrub & Mountain catchment areas & 9 \\
\hline \multirow[t]{8}{*}{ Nama and Succulent Karoo } & Prosopis species (mesquite) & Tree & Floodplains of dry rivers & 1 \\
\hline & Eucalyptus camaldulensis Dehnh. (red river gum) & Tree & Riparian zones & 2 \\
\hline & Populus species (poplars) & Tree & Riparian zones & 3 \\
\hline & Arundo donax L. (Spanish reed) & Tall reed & Riparian zones & 4 \\
\hline & Nerium oleander L. (oleander) & Shrub & Floodplains of dry rivers & 5 \\
\hline & Tamarix ramosissima Ledeb. (pink tamarisk) & Shrub & Floodplains of dry rivers & 6 \\
\hline & Schinus molle L. (pepper tree) & Tree & Landscapes & 7 \\
\hline & Myriophyllum spicatum L. (spiked water-milfoil) & Floating aquatic herb & Water bodies & 8 \\
\hline
\end{tabular}

comparing the alternatives (units to be prioritised, in this case quaternary catchments), and to carry out the prioritisation. AHP involves the following steps: (1) defining a goal; (2) identifying criteria and sub-criteria to assess alternatives in terms of their suitability for achieving the goal; (3) making pair-wise comparisons of the criteria and sub-criteria to establish their relative importance (4) making pair-wise comparisons of the alternatives with respect to the criteria, or (as in our case) making use of spreadsheets containing data relevant to each of the criteria (see Section 2.6 and Table S1).

The Expert Choice (Anonymous, 2004) software package implements AHP in a form that is convenient and explicit and can be used interactively in workshops to define the goals, criteria, subcriteria and their relative importance. The software also has the option of importing pre-determined weights for each alternative from a "data grid", and, if such data are available, their use can replace the time-consuming pair-wise comparisons of large numbers of alternatives with respect to each of the criteria. We prioritised the quaternary catchments separately within each primary catchment because each primary catchment is managed separately.

\subsection{Stakeholder workshops}

We convened two workshops in which stakeholders representing various interest groups were asked to define a goal and identify criteria and sub-criteria for prioritising alternatives with respect to achieving those goals. One focussed on the western part (primary catchments $\mathrm{E}, \mathrm{G}_{1}, \mathrm{G}_{2}$ and $\mathrm{H}$, Fig. 1) and the other on the eastern part of our study area. Workshops were attended by between 12 and 18 stakeholders drawn from three broad groups: (1) government departments responsible for water affairs, nature conservation and agriculture; (2) scientists and researchers with experience in the ecology and control of invasive alien plants; and (3) managers responsible for the implementation of alien plant control operations. The results of the exercise (a model containing weighted criteria and sub-criteria; the model is presented in Table 2) were then presented to the stakeholders at two follow-up workshops in which the model was refined in an iterative process. At the end of this process agreement was reached on the goal of prioritising quaternary catchments, namely "to reduce and control invasive alien plants to minimise their negative impacts on natural resources".

\subsection{Selection of priority invasive alien plant species}

We used the South African Plant Invaders Atlas (SAPIA, Henderson, 2007) to derive a list of species that were known to occur in $>10 \%$ of the quarter degree squares $\left(0.25^{\circ}\right.$ longitude by $0.25^{\circ}$ latitude) in the Fynbos, Succulent Karoo and Nama Karoo biomes. We used Rouget et al.'s (2004b) estimates of the area that could potentially be invaded to identify additional species that could invade $>20 \%$ of the above biomes. We used $20 \%$ (and not 10\%) as a threshold for selecting potentially problematic species given the greater degree of uncertainty involved. The combined list was then modified during workshops to exclude those species that were not considered a priority for control operations. Reasons for exclusion included that the species was under complete or substantial biological control (Klein, 2011), or that it only invaded disturbed areas, or that it did not have significant environmental impacts, particularly on water resources (for example, herbaceous species). Workshop participants then carried out pair-wise comparisons of species to rank the species in terms of their relative importance with respect to their overall impact.

\subsection{Identification of criteria and development of a prioritisation model}

Analytic hierarchy process requires that the alternatives to be prioritised (in this case quaternary catchments) be compared with each other with regard to an agreed goal and supporting criteria; and these criteria can in turn be divided into sub-criteria. We identified a goal, criteria and sub-criteria during workshops, and weighted these in a process that requires the cross-comparison of each criterion with each other criterion in terms of their relative importance for the achievement of the agreed goal. Similarly, subcriteria were compared to each other, to determine the relative importance of sub-criteria within each criterion. In this process, participants used their own understanding, and debated the relative importance of each comparison until consensus was achieved. Expert Choice (Anonymous, 2004) facilitated this process, as it continuously updates an inconsistency ratio, which allowed for the identification of inconsistent comparisons. For example, if criterion A was rated as more important than criterion $\mathrm{B}$, and $\mathrm{B}$ was rated as more important than $C$, then a subsequent allocation that rated $C$ as more important than A would show up as inconsistent. When inconsistencies arose during the model-building process, we used the opportunity to debate the relative importance assigned to each 
Table 2

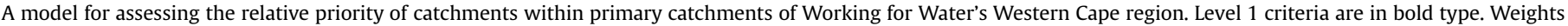

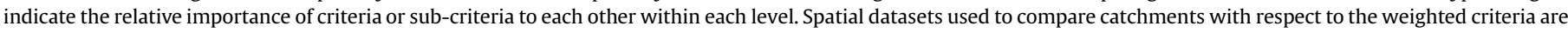
listed in supplementary material (Table S1).

\begin{tabular}{|c|c|c|}
\hline \multirow[t]{2}{*}{ Criteria and sub-criteria } & \multicolumn{2}{|c|}{ Relative weighting (\%) } \\
\hline & Level 1 criteria & Level 2 sub-criteria \\
\hline Relative capacity available to ensure that gains from control operations can be maintained & 42.4 & \\
\hline Maintenance of gains on state-owned protected areas & & 75.0 \\
\hline Maintenance of gains on other areas & & 25.0 \\
\hline Relative potential for alien plant control to contribute to the delivery of water resources & 22.3 & \\
\hline Degree to which demand for water approaches, or exceeds, ability of the water supply schemes to meet demand & & 72.2 \\
\hline Relative magnitude of water yield from area & & 20.5 \\
\hline Proportion of relatively intact river systems & & 5.5 \\
\hline Proportion of the catchment in important wetlands or floodplain aquifers & & 1.8 \\
\hline Relative degree of threat from priority invasive alien plant species & 17.3 & \\
\hline Proportion of the catchment currently invaded by priority invasive alien plants species & & 10.5 \\
\hline Proportion of the catchment covered by untransformed natural vegetation & & 63.7 \\
\hline Proportion of the catchment at risk from potential future invasion by priority invasive alien plant species & & 25.8 \\
\hline Relative importance of the area for the conservation of biodiversity & 10.4 & \\
\hline Proportion of the rivers classified as critically endangered, endangered or vulnerable & & 75.0 \\
\hline The proportion of the intact natural vegetation outside of protected areas that is classified as threatened & & 25.0 \\
\hline Relative importance of use of natural vegetation & 3.7 & \\
\hline Relative importance for the harvesting of wild flowers based on vegetation types with high proportions of harvested species & & 33.3 \\
\hline Relative importance for the harvesting of other products & & 33.3 \\
\hline Relative importance for grazing by livestock & & 33.3 \\
\hline Potential of alien plant control operations to alleviate poverty through job creation & 3.8 & \\
\hline
\end{tabular}

criterion, and to re-assign weightings until the inconsistency ratio was within acceptable limits. An inconsistency ratio of 0 indicates perfect consistency; it is recommended that the inconsistency ratio should not exceed 0.1 , and we took this into account when building our prioritisation model.

\subsection{Comparison of alternatives}

Once criteria had been agreed on, we identified spatial datasets that would allow for objective comparisons to be made between alternative quaternary catchments with regard to each of the criteria. Following the workshops, the weighting of the alternatives was completed mechanically, using the identified datasets. For each of the criteria used by the model we calculated a weight for each catchment based on the value in the respective spatial datasets we used (see Table S1). The area-based calculations were done using the ArcGIS software (ESRI, 1990-2009) and the other calculations were done using spreadsheets. The value of the output for each catchment was then divided by the corresponding total to give the final proportion or weight. The final weights were imported directly into the AHP model which then calculated the weights for each quaternary catchment for each criterion and the goal.

\section{Results}

\subsection{Priority invasive alien plant species}

We identified 17 invasive alien plant taxa (species or groups of species) that should be considered when prioritising quaternary catchments (Table 1). There were nine taxa in the Fynbos biome, all of which were trees except one, Hakea sericea, a tall shrub. Some of them, notably Acacia species, tend to be more prominent in the lowlands, while Pinus species and $H$. sericea invade inaccessible mountain catchment areas. In the Karoo biomes, four of the eight taxa were trees, two were shrubs, and there was one tall reed and one floating aquatic weed. Several species in both biomes are aggressive invaders of riparian zones and dry riverbeds (Table 1).

\subsection{Development of a prioritisation model}

Workshop participants agreed that the goal of prioritisation was to protect natural ecosystems and the services that they deliver through the reduction and containment of invasions of priority invasive alien plant species. The participants identified six criteria (divided hierarchically into 15 sub-criteria, Table 2 ) that could be used to determine the relative importance of alternatives (quaternary catchments) in terms of achieving the goal. The resultant model reflects the agreed weights assigned by the workshop participants. As the criteria and weightings defined in the two subsections of our study area overlapped to a significant degree, we combined them into a single model presented in Table 2 .

The criterion given the greatest weight $(42.4 \%)$ was the existence of management capacity to ensure that gains (i.e. cleared areas or reduced densities) resulting from control operations could be maintained. This ability was compared at two levels. First, catchments were compared with respect to the extent of stateowned protected areas, where alien plant control is a management objective and sufficient management capacity existed. Workshop participants felt strongly that private landowners frequently failed to continue alien control treatments even where they had signed contracts which ostensibly bound them to do so. Privately-owned land was therefore given a lower weighting, and catchments were compared with respect to the extent of privatelyowned land that fell within a proclaimed mountain catchment area where South African legislation (Mountain Catchment Areas Act, No 63 of 1970) enables the state to compel landowners to do the necessary management or, alternatively, to undertake the work and compel the land-owner to pay the resulting costs.

The potential for alien plant control to contribute to the delivery of water resources was given a relative weighting of $22.3 \%$. This potential was evaluated at four levels. The most important of these was the degree to which demand for water approached or exceeded supply, as this would be where invasive alien plant clearing would deliver the greatest benefit in terms of relieving water stress. Catchments that yielded more water were also prioritised over drier catchments for the same reason. Finally, catchments with a greater length of rivers in a natural or near natural state (Table S1), or a greater proportion of wetlands or floodplain 
aquifers were given higher priority because invasive alien plants in these settings use more water than those in the adjacent dryland areas. Floodplain aquifers were regarded as particularly important in the Nama and Succulent Karoo biomes, where many rivers are non-perennial and groundwater in alluvial deposits is a key water source.

The relative current and potential levels of invasion by priority alien invasive plant species (Table 1) were given a weighting of 17.3\%. Catchments were compared in terms of this criterion at three levels: addressing the current extent of invasion by priority species; (2) the potential extent of invasion; and (3) the proportion of the catchment still un-invaded. The principle was to give a higher priority to catchments with the greatest proportion of un-invaded natural vegetation remaining, and where further invasions could have the greatest impact.

The relative importance of the area for the conservation of biodiversity was given a weight of $10.4 \%$, and both terrestrial biodiversity (threatened vegetation types), and the biodiversity of river systems (threatened river types) were considered. The biodiversity criteria enabled the promotion of catchments that were endowed with particularly important biodiversity outside of protected areas over catchments relatively poor in biodiversity, particularly in lowland areas which have low water yields and are largely privately-owned.

Two other criteria (the use of natural vegetation, and the potential to create employment) were identified, but each was given a weight of $<4 \%$, and thus contributed relatively little to the final outcome of the prioritisation exercise. This was both because the workshop participants rated the other criteria as more important, and, in the case of employment, it was felt that poverty was ubiquitous. This meant that there were more people eligible for employment in any given catchment than Working for Water could accommodate, justifying a low weight.

\subsection{Model outputs}

We identified 12 spatial datasets that could be used to produce the weights used to compare the quaternary catchments (Table S1). Quaternary catchments allocated the highest priority in each of the primary catchments included those with a large proportion of state-owned, protected land, a high degree of water stress, and a high water yield. These catchments were generally in the headwaters of primary catchments (Fig. 3), and their location

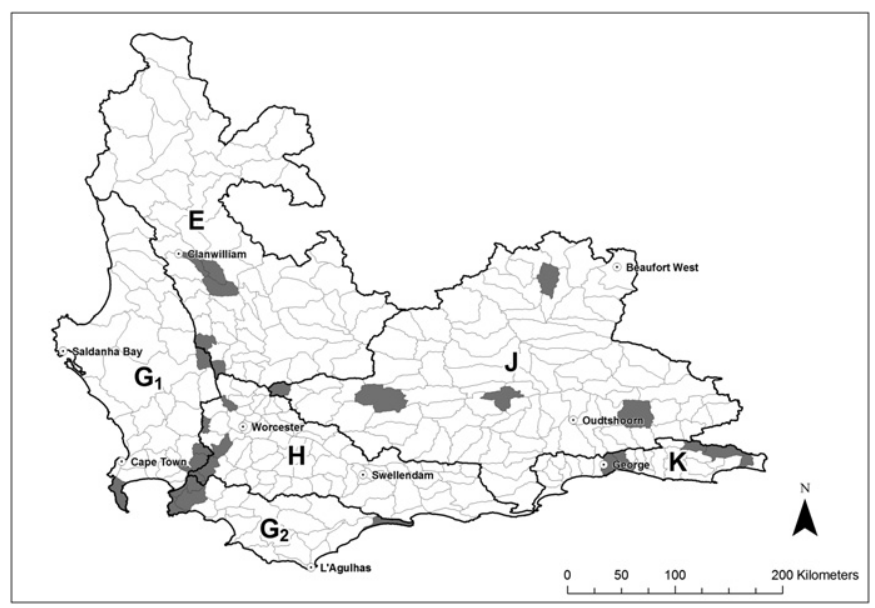

Fig. 3. Primary catchments in Working for Water's Western Cape region, showing the five quaternary catchments that were rated as the highest priority in each primary catchment. reflects the criteria that were allocated the greatest weights, namely the capacity to ensure that gains from control operations can be maintained (primarily interpreted as being on stateowned, protected land) and the potential of control to contribute to the delivery of water (Table 2, Fig. 4). The inclusion of criteria with moderate weightings (the relative threat of invasions and the conservation of biodiversity) only had a limited effect on the outcomes by slightly changing the relative ranking of individual quaternary catchments (Fig. 4). However, the inclusion of criteria with low weightings ( $<4 \%$, including the use of natural vegetation, and the potential to alleviate poverty) did not affect the outcomes.

\section{Discussion}

\subsection{Combining stakeholder input and spatial data}

This study has demonstrated the potential for combining stakeholder priorities (to identify and weight criteria) with spatial datasets to derive a set of priority areas. We prioritised 309 quaternary catchments within six primary catchments using 15 criteria. This could not have been completed manually in a workshop environment as it would have required over 100000 crosscomparisons. However, by using spatial data to generate weights for each alternative (quaternary catchments) relative to the criteria, Expert Choice (Anonymous, 2004) enabled us to automate this evaluation process.

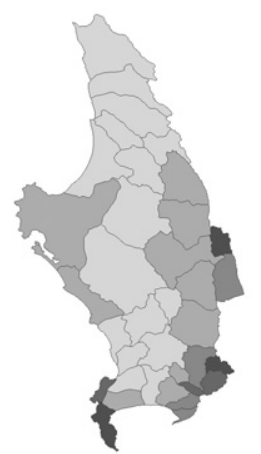

Maintain gains

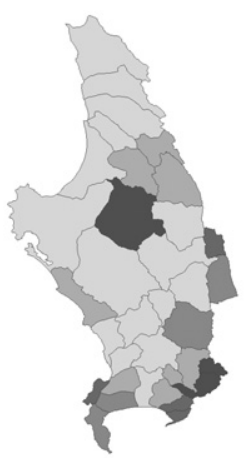

Protect water resources

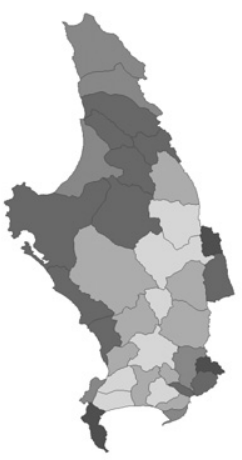

Threat of invasion

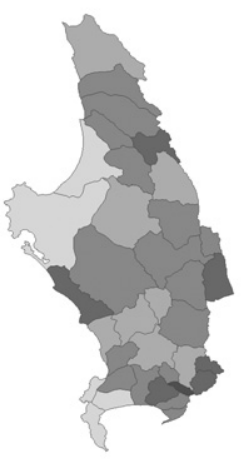

Biodiversity

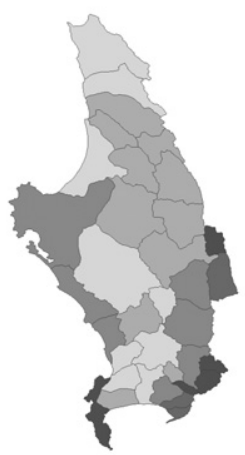

All criteria
Fig. 4. Comparison of the priorities for each quaternary catchment in primary catchment $G_{1}$ based on the four most important criteria and all the criteria in the AHP model (see Table 2). Darker shading indicates catchments having a higher priority for the control of invasive alien plants. 


\subsection{Challenges in implementation}

Invasive alien plant control programs have been conducted in the Western Cape Province for many decades prior to the founding of Working for Water in 1996 (Fenn, 1980; Macdonald et al., 1989), and for 15 years since then. On completion of our prioritisation exercise, we compared expenditure by Working for Water in individual catchments to the priority of those catchments, and found reasonable agreement in some cases but not in others (Forsyth et al., 2009). In many cases catchments given the highest priority did not have any clearing projects while others with low priorities received funding (Forsyth et al., 2009). Clearly there is a need to realign priorities and to either reallocate funds or direct any additional funds to the highest priority catchments or do both.

Experience has shown that successful control projects require clear, time-based goals, adequate resources to achieve the desired level of control, and actual and in-kind support from the stakeholders. The process followed here has established a set of clear, transparent and agreed priorities which must now be used to guide the reallocation of the available funds. We suggest that the funds should be re-allocated in proportion to the agreed priorities while taking account of the need to phase out existing projects in low priority catchments. This process should be applied to catchments in order of priority until all available funds are allocated.

The priorities that we have identified provide a useful and transparent basis for making defensible choices regarding the allocation of funds. However, the identification of priorities themselves is clearly not sufficient in itself, and in cases where a large number of alternatives exists, it will still be necessary to decide how many, and to what extent, the alternatives receive funding.

\section{Acknowledgements}

This work was funded by Working for Water and the CSIR (Parliamentary Grant Project Multi-functional landscapes). We thank workshop participants for their valuable inputs, and Andrew Wannenburgh, Derek Malan and Ruhwene Miles for valuable additional support.

\section{Appendix. Supplementary material}

Supplementary material associated with this article can be found, in the online version, at doi:10.1016/j.jenvman.2012.01.034.

\section{References}

Anonymous, 2004. Expert Choice 11.5. Expert Choice Inc., Pittsburgh, PA, United States of America.

Blignaut, J., Milton, S., Cupido, C., 2005. The Economic Value of Controlling Invasive Alien Plant Species in the Karoo. Unpublished report, October 2005. Working for Water, Cape Town.

DWAF, September 2004. National Water Resources Strategy, first ed. Department of Water Affairs and Forestry, Pretoria, South Africa.

Environmental Systems Research Institute (ESRI), 1990. Arc/Info Command Line; ArcView Desktop GIS Software Versions 3.x.; ArcGIS 9.3.1. ESRI, Redlands, California.

FAO, 2003. In: Labrada, R. (Ed.), Expert Consultation on Weed Risk Assessment. Food and Agriculture Organization of the United Nations, Rome.

Fenn, J.A., 1980. Control of Hakea in the western Cape. In: Neser, S., Cairns, A.L.P. (Eds.), Proceedings of the Third National Weeds Conference of South Africa. Balkema, Cape Town, pp. 167-173.

Forsyth, G.G., Le Maitre, D.C., van Wilgen, B.W., 2009. Prioritising Quaternary Catchments for Invasive Alien Plant Control Within the Fynbos and Karoo Biomes of the Western Cape Province. Report No. CSIR/NRE/ECO/ER/2009/0094/ B. Natural Resources and the Environment, CSIR, Stellenbosch.

Groves, R.H., Hosking, J.R., Batianoff, G.N., Cooke, D.A., Cowie, I.D., Johnson, R.W., Keighery, G.J., Lepschi, B.J., Mitchell, A.A., Moerkerk, M., Randall, R.P., Rozenfelds, A.C., Walsh, N.G., Waterhouse, B.M., 2003. Weed Categories for Natural and Agricultural Ecosystem Management. Bureau of Rural Sciences, Canberra.
Hauser, C.E., McCarthy, M.A., 2009. Streamlining ‘search and destroy': cost-effective surveillance for invasive species management. Ecology Letters 12, 683-692.

Henderson, L., 2007. Invasive, naturalized and casual alien plants in southern Africa: a summary based on the Southern African Plant Invaders Atlas (SAPIA). Bothalia 37, 215-248.

Herath, G., 2004. Incorporating community objectives in improved wetland management: the use of the analytic hierarchy process. Journal of Environmental Management 70, 263-273.

Higgins, S.I., Richardson, D.M., Cowling, R.M., 2000. Using a dynamic landscape model for planning the management of alien plant invasions. Ecological Applications 10, 1833-1848.

Klein, H., 2011. A catalogue of the insects, mites and pathogens that have been used or rejected, or are under consideration, for the biological control of invasive alien plants in South Africa. African Entomology 19, 515-549.

Le Maitre, D.C., van Wilgen, B.W., Chapman, R.A., McKelly, D.H., 1996. Invasive plants in the Western Cape, South Africa: modelling the consequences of a lack of management. Journal of Applied Ecology 33, 161-172.

Le Maitre, D.C., Versfeld, D.B., Chapman, R.A., 2000. The impact of invading alien plants on surface water resources in South Africa: a preliminary assessment. Water SA 26, 397-408.

Macdonald, I.A.W., Clark, D.L., Taylor, H.C., 1989. The history and effects of alien plant control in the Cape of Good Hope Nature Reserve, 1941-1947. South African Journal of Botany 55, 56-75.

Mack, M.C., Simberloff, D., Lonsdale, W.M., Evans, H., Clout, M., Bazzaz, F.A., 2000 Biotic invasions: causes, epidemiology, global consequences, and control. Ecological Applications 10, 689-710.

Magadlela, D., Mdzeke, N., 2004. Social benefits in the Working for Water programme as a public works initiative. South African Journal of Science 100, 94-96.

Mgidi, T.N., Le Maitre, D.C., Schonegevel, L., Nel, J.L., Rouget, M., Richardson, D.M. 2007. Alien plant invasions - incorporating emerging invaders in regional prioritization: a pragmatic approach for southern Africa. Journal of Environmental Management 84, 173-187.

Mittermeier, R.A., Myers, N., Thorsen, J.B., da Fonseca, G.A.B., Olivieri, S., 1998. Biodiversity hotspots and major tropical wilderness areas: approaches to setting conservation priorities. Conservation Biology 12, 516-520.

Moody, M.E., Mack, R.N., 1988. Controlling the spread of plant invasions: the importance of nascent foci. Journal of Applied Ecology 25, 1009-1021.

Mucina, L., Rutherford, M.C. (Eds.), 2006. The Vegetation of South Africa, Lesotho and Swaziland. Strelitzia 19. South African National Biodiversity Institute, Pretoria.

Nel, J.L., Richardson, D.M., Rouget, M., Mgidi, T., Mdzeke, N., Le Maitre, D.C., van Wilgen, B.W., Schonegevel, L., Henderson, L., Neser, S., 2004. A proposed classification of invasive alien plant species in South Africa: towards prioritizing species and areas for management action. South African Journal of Science 100, 53-64.

Olenick, K.L., Wilkins, R.N., Conner, J.R., 2004. Increasing off-site water yield and grassland bird habitat in Texas through brush treatment practices. Ecological Economics 49, 469-484.

Omkarprasad, S.V., Kumar, S., 2006. Analytic hierarchy process: an overview of applications. European Journal of Operational Research 169, 1-29.

Pheloung, P.C., Williams, P.A., Halloy, S.A., 1999. A weed risk assessment model for use as a biosecurity tool evaluating plant introductions. Journal of Environmental Management 57, 239-251.

Qureshi, M.E., Harrison, S.R., 2001. A decision support process to compare riparian revegetation options in Scheu Creek catchment in North Queensland. Journal of Environmental Management 62, 101-112.

Ramanathan, R., 2001. A note on the use of analytic hierarchy process for environmental impact assessment. Journal of Environmental Management 63, 27-35.

Regan, H.M., Colyvan, M., Markovchick-Nicholls, L., 2006. A formal model for consensus and negotiation in environmental management. Journal of Environmental Management 80, 167-176.

Richardson, D.M., van Wilgen, B.W., 2004. Invasive alien plants in South Africa: how well do we understand the ecological impacts? South African Journal of Science 100, 45-52.

Richardson, D.M., Macdonald, I.A.W., Hoffmann, J.H., Henderson, L., 1997. Alien plant invasions. In: Cowling, R.M., Richardson, D.M., Pierce, S.M. (Eds.), Vegetation of Southern Africa. Cambridge University Press, Cambridge, UK, pp. 534-570.

Robertson, M.P., Villet, M.H., Fairbank, D.H.K., Henderson, L., Higgins, S.I., Hoffmann, J.H., Le Maitre, D.C., Palmer, A.R., Riggs, I., Shackleton, C.M., Zimmermann, H.G., 2003. A proposed prioritization system for the management of invasive alien plants in South Africa. South African Journal of Science 99, 37-44.

Rouget, M., Reyers, B., Jonas, Z., Desmet, P., Driver, A., Maze, K., Egoh, B., Cowling, R.M., 2004a. South African National Spatial Biodiversity Assessment 2004: Technical Report. In: Terrestrial Component, vol. 1. South African National Biodiversity Institute, Pretoria.

Rouget, M., Richardson, D.M., Nel, J., Le Maitre, D.C., Egoh, B., Mgidi, T., 2004b. Mapping the potential ranges of major plant invaders in South Africa, Lesotho and Swaziland using climatic suitability. Diversity and Distributions 10, 475-484.

Roura-Pascual, N., Richardson, D.M., Krug, R.M., Brown, A., Chapman, R.A., Forsyth, G.G., Le Maitre, D.C., Robertson, M.P., Stafford, L., van Wilgen, B.W., Wannenburgh, A., Wessels, N., 2009. Ecology and management of alien plant invasions in South African fynbos: accommodating key complexities in objective decision making. Biological Conservation 142, 1595-1604. 
Ruesink, J.L., Parker, I.M., Groom, M.J., Kareiva, P., 1995. Reducing the risks of nonindigenous species introductions. BioScience 45, 465-477.

Saaty, T.L., 1990. How to make a decision: the analytic hierarchy process. European Journal of Operational Research 48, 9-26.

Shackleton, C., Shackleton, S., Gamzbiza, J., Nel, E., Rowntree, K., Urquhart, P., 2008. Links Between Ecosystem Services and Poverty Alleviation: Situation Analysis for Arid and Semi-arid Lands in Southern Africa. Ecosystem Services and Poverty Reduction Research Programme: DFID, NERC, ESRC. DFID, UK.

Skurka Darin, G.M., Shoenig, S., Barney, J.N., Panetta, F.D., DiTomaso, J.M., 2011 WHIPPET: a novel tool for prioritizing invasive plant populations for regional eradication. Journal of Environmental Management 92, 131-139.

Turpie, J.K., Heydenrych, B.J., Lamberth, S.J., 2003. Economic value of terrestrial and marine biodiversity in the Cape Floristic Region: implications for defining effective and socially optimal conservation strategies. Biological Conservation $112,233-251$. van Wilgen, B.W., Le Maitre, D.C., Cowling, R.M., 1998. Ecosystem services, efficiency, sustainability and equity: South Africa's Working for Water programme. Trends in Ecology and Evolution 13, 378.

van Wilgen, B.W., Nel, J.L., Rouget, M., 2007. Invasive alien plants and South African rivers: a proposed approach to the prioritization of control operations. Freshwater Biology 52, 711-723.

van Wilgen, B.W., Reyers, B., Le Maitre, D.C., Richardson, D.M., Schonegevel, L., 2008. A biome-scale assessment of the impact of invasive alien plants on ecosystem services in South Africa. Journal of Environmental Management 89, 336-349.

van Wilgen, B.W., Khan, A., Marais, C., 2010. Changing perspectives on managing biological invasions: insights from South Africa and the Working for Water programme. In: Richardson, David M. (Ed.), Fifty Years of Invasion Ecology: The Legacy of Charles Elton. Wiley-Blackwell, pp. 377-393.

Working for Water, 2007. The Working for Water Programme Strategic Plan 2008-2012. Working for Water, Cape Town. 